\title{
Genetic architecture of limit dextrinase inhibitor (LDI) activity in Tibetan wild barley
}

\author{
Yuqing Huang ${ }^{1}$, Shengguan Cai ${ }^{1}$, Lingzhen Ye ${ }^{1}$, Yong Han ${ }^{1}$, Dezhi Wu${ }^{1}$, Fei Dai ${ }^{1}$, Chengdao Li $^{2}$ and Guoping Zhang ${ }^{1 *}$
}

\begin{abstract}
Background: Limit dextrinase inhibitor (LDI) inhibits starch degradation in barley grains during malting because it binds with limit dextrinase (LD). There is a wide genetic variation in LDI synthesis and inactivation during barley grain development and germination. However, the genetic control of LDI activity remains little understood.

Results: In this study, association analysis was performed on 162 Tibetan wild accessions by using LDI activity, 835 Diversity Arrays Technology (DArT) markers and single nucleotide polymorphisms (SNPs) of the gene HvLDl encoding LDI. Two DArT markers, bpb-8347, bpb-0068, and 31 SNPs of HVLDI were significantly associated with LDI activity, explaining $10.0 \%, 6.6 \%$ and $13.4 \%$ of phenotypic variation, respectively. Bpb-8347 is located on chromosome $6 \mathrm{H}$, near the locus of HVLDI, and bpb-0068 is located on $3 \mathrm{H}$.

Conclusions: The current results confirmed the locus of the gene controlling LDI activity and identified a new DArT markers associated with LDI activity. The SNPs associated with LDI activity may provide a new insight into the genetic variation of LDI activity in barley grains.
\end{abstract}

Keywords: Limit dextrinase inhibitor (LDI), Genome-wide association study (GWAS), Single nucleotide polymorphism (SNP), Tibetan wild barley

\section{Background}

Malting is the first step in brewing or beer production of malt barley, and the properties of malting barley are generally evaluated on the basis of malting quality. High malting quality is characterized by high malt extract (ME) and diastatic power (DP), as well as high wort fermentation by yeast, i.e. complete degradation of starch and polysaccharide in malt [1]. The major chemical compound in barley grains is starch, which consists of $30 \%$ amylose and $70 \%$ amylopectin [2].

Starch is degraded by coordinative action of $\alpha$-amylase, $\beta$-amylase, limit dextrinase (LD) and $\alpha$-glucosidase in the endosperm of the germinating grains [3]. LD is the only enzyme of cleaving $\alpha-1-6$ linkages in branched dextrins molecules [4]. Without the action of LD, the branched dextrins could not be fermented by yeast [5]. Hence, LD plays an important role in the brewing and distilling industries for producing fermentable sugar.

\footnotetext{
* Correspondence: zhanggp@zju.edu.cn

${ }^{1}$ Agronomy Department, Key Laboratory of Crop Germplasm Resource of Zhejiang Province, Zhejiang University, Hangzhou 310058, China

Full list of author information is available at the end of the article
}

LD in barley grains exists in three different forms: insoluble bound, soluble inactive and active free, and only the active free form participates in starch mobilization [6]. However, the free LD accounts for a small portion of total LD. The low activity of available LD in grains is due to its combination with endogenous inhibitors, limit dextrinase inhibitor (LDI) [7]. LD and LDI interact with each other in a 1:1 molar ratio complex [8]. The LD bound to LDI is thought to be a limiting factor for complete degradation of starch [9].

LDI is synthesized in the developing grains, and degraded gradually during the malting process [7]. Consequently, LD activity in malt is not only dependent on the amount of the enzyme itself in mature grains, and also is closely related to the amount and type of LDI. HvLDI was identified to encode the LDI protein, and located at chromosome $6 \mathrm{H}$ $[10,11]$. However, genetic variation and controlling of LDI synthesis and degradation in barley grains and malt is not totally understood. In view of a wider variation of LD activity in Tibetan wild barley than in cultivated barley (unpublished data), it is imperative to determine the genetic variation of LDI content in Tibetan wild barley, 
which has been recently proved to be a progenitor of cultivated barley and is rich in genetic diversity $[12,13]$.

Association analysis has been widely used to identify genes or loci of important traits, such as abiotic stress tolerance $[14,12,15]$, agronomic traits $[16,17]$ and also barley quality $[18,19]$. However, there has been no report on the discovery of novel loci or elite alleles attributed to LDI activity using association analysis.

The objectives of this study were to (1) determine the genetic variation of LDI activity in Tibetan wild barley; (2) identify the DArT markers and SNPs of $H v L D I$ associated with LDI activity in Tibetan wild barley.

\section{Methods}

\section{Plant materials}

A total of 162 Tibetan wild barley accessions, kindly provided by professor Sun of Huazhong Agricultural University, China, were used for LDI activity and association analysis. All accessions were planted in early November 2011 and 2012 in Zijingang campus, Zhejiang University (Hangzhou, China). Every genotype was cultivated in accordance with local agronomic practices with three replications. The 162 barley accessions were planted in a block with each accession consisting of three lines ( $2 \mathrm{~m}$ length and line distance is $0.25 \mathrm{~m}$ ).

\section{Assay of LDI activity}

Grain samples were micro-malted in a Phoenix System Micro-malting Apparatus (Adelaide, Australia) in the order of steeping, germination and drying. LD was partially purified from barley malt according to Kristensen et al. [20]. The fractions were applied to gel filtration chromatography after the ion exchange chromatography step, and partially purified LD was collected and used for the measurement of LDI activity.

LDI activity was determined according to MacGregor et al. [21] with some modification. One $\mathrm{ml}$ of $0.1 \mathrm{M}$ sodium acetate ( $\mathrm{pH}$ 5.5) containing $10 \mathrm{mM}$ 1,10-phenanthroline was added to $0.1 \mathrm{~g}$ barley powder, incubated at $4^{\circ} \mathrm{C}$ for $30 \mathrm{~min}$. The extract was heated at $70^{\circ} \mathrm{C}$ for $40 \mathrm{~min}$, centrifuged and the supernatant was collected. The protein content of the extracts was measured using Bradford assay kits (Sangon Biotech). Twenty micrograms protein of LDI extract were mixed with $10 \mathrm{mU}$ partially purified LD and the volume was made up to $0.5 \mathrm{ml}$ in $0.1 \mathrm{M}$ maleic acid containing $0.02 \% \mathrm{Na}$ azide ( $\mathrm{pH}$ 5.5). The remaining LD was determined using the LimitDextrinase assay kit (Megazyme). The LDI activity was calculated as the reduced LD activity.

\section{Population structure and kinship analysis}

Totally, 771 DArT markers, with minor allele frequency (MAF) higher than 0.03 (Additional file 1: Table S1), were used for population structure analysis using STRUCTURE software (v2.3.3) [22], in which the number of clusters (k) was set from 1 to 12 and ten iterations were performed in an admixture model with 10,000 burning period and 100,000 MCMC (Markov Chain Monte Carlo). The DArT markers used were derived from Diversity Arrays Technology Pty Ltd, Australia and distributed over the whole genome [23-25]. The most probable number of clusters (k) was estimated according to the value of $\Delta \mathrm{k}$. When $\Delta \mathrm{k}$ had the highest value, the value of $k$ was the number of clusters [26]. Kinship was estimated using SPAGeDi software [27]. Genetic distance and neighbor-joining tree were developed with NTSYSpc (version 2.10e).

\section{Variance component and heritability estimation}

Variance analysis was conducted using SPSS software. The used model was: $y=m u+$ GENOTYPE + ERROR (fixed in low case, random in capitals). Heritability was estimated according to $\mathrm{H}^{2}=\mathrm{Vg} /(\mathrm{Vg}+\mathrm{Ve})$.

\section{Genome-wide association study (GWAS) of LDI activity}

Genome-wide association study between LDI activity (mean value of 2011 and 2012) and DArT markers was conducted using TASSEL software (v3.0), where Q, K and $\mathrm{Q}+\mathrm{K}$ methods were applied [28]. The structure matrix was included as covariate to correct population structure in Q model: $y=Q v+X \beta+e$, where $X$ is the DArT marker matrix, $Q$ is the structure matrix, $\beta$ and $v$ are coefficient vectors for DArT marker vector and population structure vector, and e is the random error vector. In $\mathrm{K}$ model: $y=X \beta+Z u+e$. The $\mathrm{Q}+\mathrm{K}$ model can be written in a matrix form as: $y=Q v+X \beta+Z u+e$, where $X, \beta, Q$ and $v$ are the same as those mentioned above, $Z$ is the kinship matrix, and $u$ is a vector of random genetic effects $\mathrm{u} \sim \mathrm{N}(0,2 \mathrm{~K})$, where $\mathrm{K}$ is the kinship matrix. Manhattan plots were displayed using $\mathrm{R}$ software (v2.14.2).

\section{PCR amplification and sequencing}

Genomic DNA was extracted from leaves of 150 barley seedlings using CTAB method [29]. The primers used for DNA amplification were designed using the primer design tool of NCBI (http://www.ncbi.nlm.nih.gov/tools/primerblast/). Primers for $H v L D I$ were: forward, TTTTCGCA TGTCACCAAAAATGT; reverse, TCCGCTTCATTACCT TGGCG. The amplified DNA fragment was about $900 \mathrm{bp}$.

The PCR reactions were completed as follows: $2.5 \mu \mathrm{l}$ of $10 \times$ TransTaq HiFi buffer I (200 mM Tris- $\mathrm{HCl}(\mathrm{pH} 8.4)$, $100 \mathrm{mM}\left(\mathrm{NH}_{4}\right)_{2} \mathrm{SO}_{4}, 20 \mathrm{mM} \mathrm{MgCl} 2,200 \mathrm{mM} \mathrm{KCl}, 2 \mu \mathrm{l}$ of $2.5 \mathrm{mM}$ dNTPs, $1 \mu \mathrm{l}$ of $10 \mu \mathrm{M}$ forward primers, $1 \mu \mathrm{l}$ of $10 \mu \mathrm{M}$ reverse primer, $0.5 \mu \mathrm{l}$ of 5 units $\mu^{-1}$ of TransTaq polymerase High Fidelity (Beijing TransGen Biotech Co., Ltd.), and $1 \mu \mathrm{l}$ of $50 \mathrm{ng}$ of genomic DNA. The PCR amplification program started at $5 \mathrm{~min}$ at $95^{\circ} \mathrm{C}$, followed by 32 cycles of $30 \mathrm{~s}$ at $95^{\circ} \mathrm{C}, 30 \mathrm{~s}$ at $60^{\circ} \mathrm{C}$, and $1 \mathrm{~min}$ at $72^{\circ} \mathrm{C}$, 


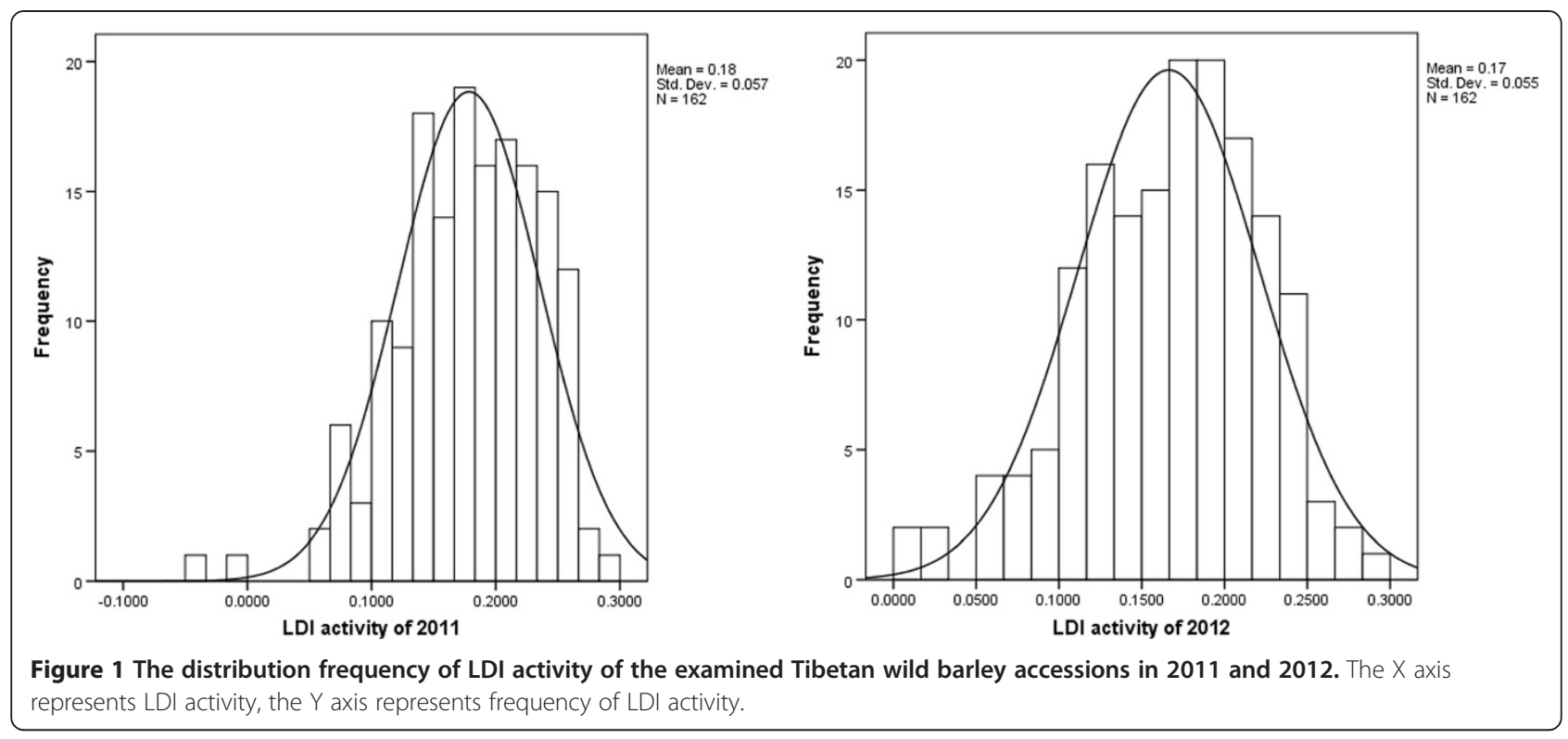

and then $10 \mathrm{~min}$ at $72^{\circ} \mathrm{C}$ for a final extension. The PCR products were analyzed by $1 \%$ agarose gel electrophoresis. They were sequenced using $3730 \times 1$ DNA Analyzer (Applied Biosystems Inc., USA).

\section{Polymorphism of HvLDI and haplotype analysis}

Alignment and polymorphism detection of $H v L D I$ sequences were analyzed by MEGA v5.2 [30]. The haplotype analysis was conducted with Dnasp v5.0 [31].

\section{Availability of supporting data}

The sequences of the 6 haplotypes were deposited in GenBank, and the accession numbers of these haplotypes, H1-H6 are KJ710426, KJ710427, KJ710427, KJ710429, KJ710430 and KJ710431, respectively.

\section{Results}

\section{LDI activities of 162 Tibetan wild accessions}

A wide genetic variation of the LDI activity was observed among 162 Tibetan barley accessions for two years (Figure 1), ranged from $-0.034 \mathrm{mU} / \mu \mathrm{g}$ to $0.295 \mathrm{mU} / \mu \mathrm{g}$ for 2011 and from $0.003 \mathrm{mU} / \mu \mathrm{g}$ to $0.287 \mathrm{mU} / \mu \mathrm{g}$ for 2012, with a mean of $0.176 \mathrm{mU} / \mu \mathrm{g}$ and standard difference (SD) of 0.057 for 2011 samples, and a mean of $0.167 \mathrm{mU} / \mu \mathrm{g}$ and SD of 0.055 for 2012 .

Table 1 Variance component and heritability $\left(\mathrm{H}^{2}\right)$ estimates for LDI activity of 2011 and 2012

\begin{tabular}{lccc}
\hline & $\mathbf{V g}$ & $\mathbf{V e}$ & $\mathbf{H}^{\mathbf{2}}$ \\
\hline Year 2011 & $3.20 \mathrm{E}-03$ & $2.88 \mathrm{E}-04$ & 0.928 \\
Year 2012 & $2.48 \mathrm{E}-03$ & $4.93 \mathrm{E}-04$ & 0.854
\end{tabular}

Note: Variance components are shown for Genotype (Vg), Error (Ve).
The results of variance analysis are presented in Table 1. Estimates of the variance component for genotype and error were 0.00320 and 0.000248 for 2011, 0.00288 and 0.000493 for 2012. The heritabilities for 2011 and 2012 were 0.928 and 0.854 , respectively.

\section{Population structure}

The largest value of statistic index $\Delta \mathrm{k}$ was used as an indicator of the most probable number of subpopulations for all accessions (Figure 2). In the present study, the 162 accessions could be classified into five subpopulations, with 19, 17, 21, 50 and 55 accessions for the each individual subpopulation (Figure 3). The result was consistent with the data from the cluster analysis (Additional file 2: Figure S1). The population structure of 162 Tibetan wild barley accessions was listed in Additional file 3: Table S2.

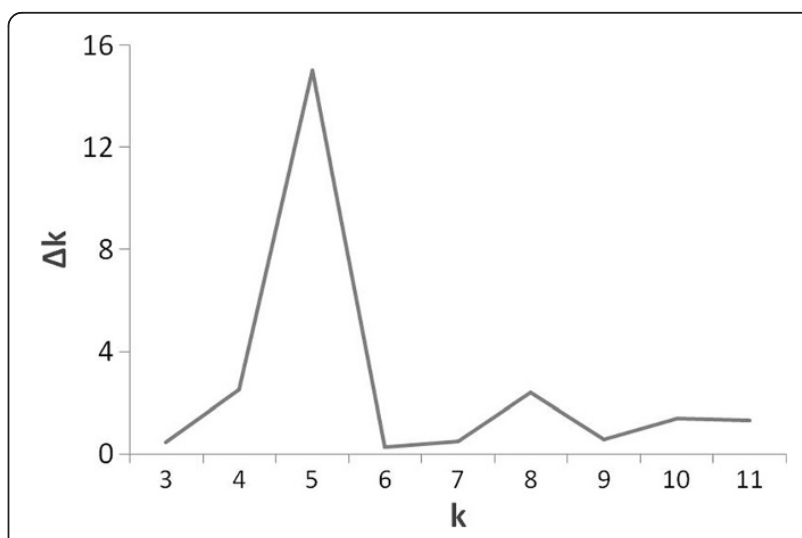

Figure 2 Estimation of the most probable number of clusters (k), based on 10 independent runs and k ranging from 1 to 11 . 


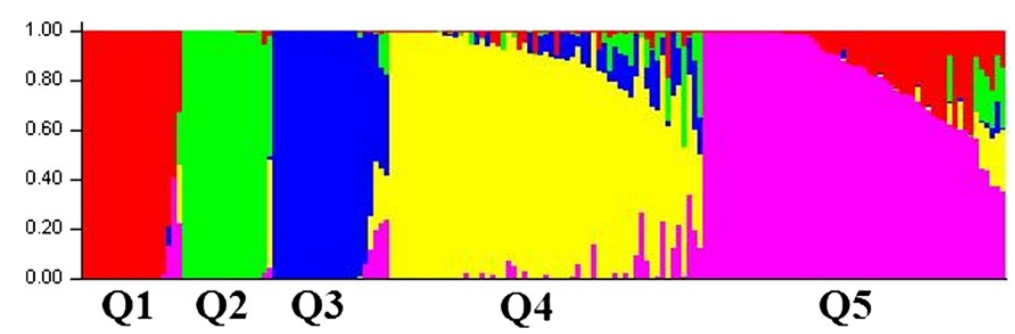

Figure 3 Population structure of 162 Tibetan barley accessions. Population structure of 162 barley accessions was divided based on genetic diversity detected by 835 DArT markers with $k=5$. Five subpopulations were represented by different colors.

\section{Genome-wide association study}

The LDI activities of 162 accessions and 771 DArT markers were used to perform genome-wide association study (GWAS). Two markers, bpb-8347 and bpb-0068 showed significance under $\mathrm{Q}, \mathrm{K}$ and $\mathrm{Q}+\mathrm{K}$ methods (Additional file 4: Table S3). When $\mathrm{Q}$ method was used, the $-\log _{10}(\mathrm{p})$ values for bpb-8347 and bpb-0068 were 5.48 and 3.75 in 2011 and 7.76 and 4.26 in 2012. If only kinship was considered, the $-\log _{10}(\mathrm{p})$ values for bpb-8347 and bpb-0068 were 2.40 and 2.25 in 2011, and 3.10 and 2.15 in 2012. When a more restrict method, Q + K method was applied, the $-\log _{10}(\mathrm{p})$ values were 2.75 and 2.30 in 2011, and 3.74

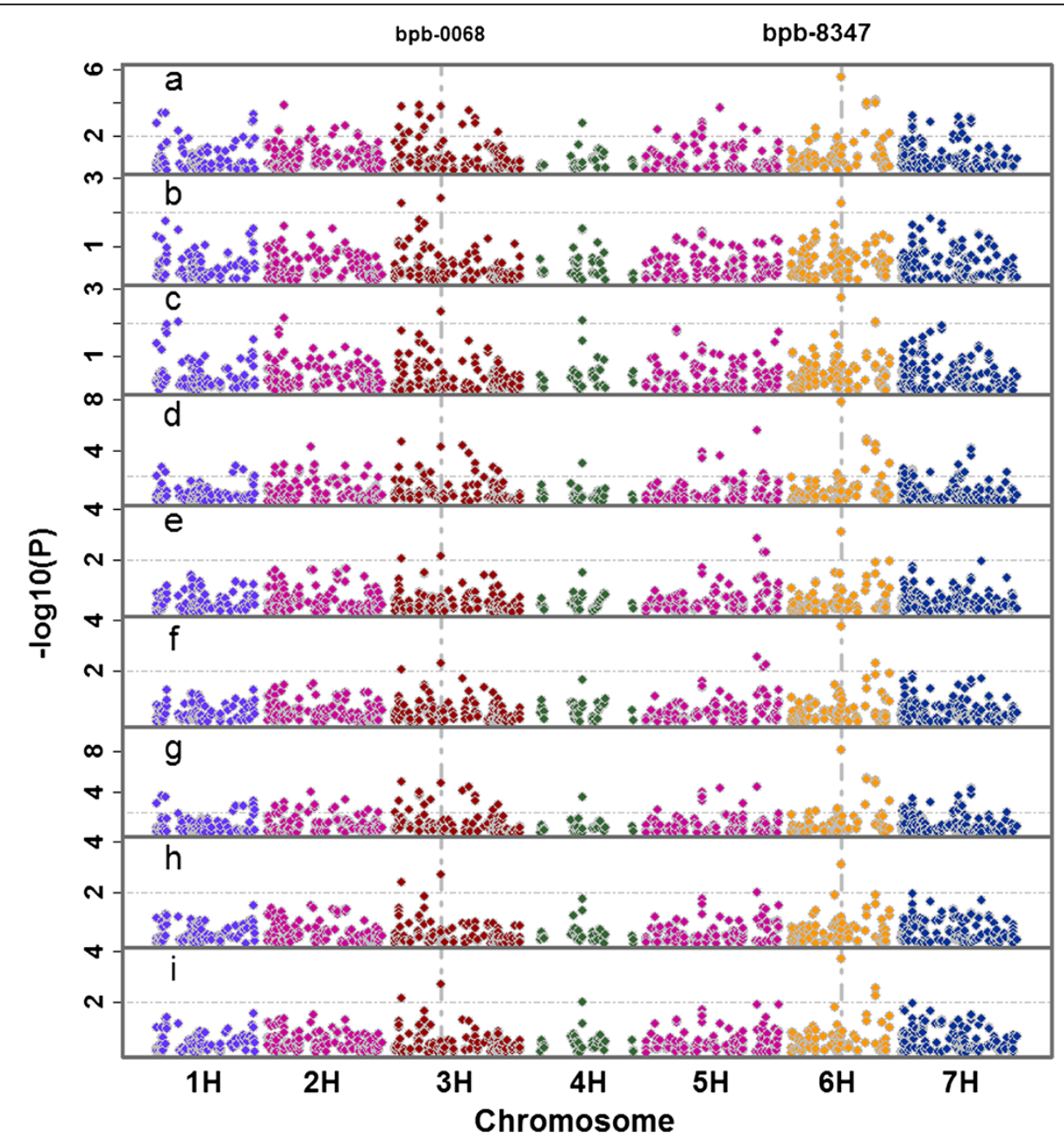

Figure 4 GWAS of LDI activity of 162 Tibetan barley accessions. GWAS was analyzed by three methods: a, d and g: Q method for 2011,2012 and mean values of 2011 and 2012; b, e, h: K method for 2011, 2012 and mean values; b, d and f: Q + K method for 2011, 2012 and mean values. Significant associations were identified using criterion of $-\log _{10}(P)>2(P<0.01)$. 
and 2.29 in 2012, all of which reached the threshold of significance in association analysis: $-\log 10(\mathrm{P})=2$ (Figure 4). For the mean LDI activity of the two years, the $-\log _{10}(\mathrm{p})$ values for bpb-8347 and bpb-0068 were 8.07 and 4.88, respectively, if considered from only one population structure, and 3.06 and 2.66 if only kinship being considered, and 3.70 and 2.71 , if both population structure and kinship being considered.

Bpb-8347 and bpb-0068, located at 73.44 cM on chromosome $6 \mathrm{H}$ and $66.50 \mathrm{cM}$ on $3 \mathrm{H}$, showed significant associations with LDI activity, explaining $6.8 \%$ and $5.3 \%$ of phenotypic variation in 2011 and $10.4 \%$ and $5.5 \%$ in 2012 under Q + k method. Similarly, the two DArT markers could explain $10.0 \%$ and $6.6 \%$ of phenotypic variation for the mean values of 2011 and 2012.

\section{Association between HvLDI and LDI activity and haplotype analysis}

The variation of $H v L D I$ and its promoter region were further investigated because several evidences supported the existence of a major gene responsible for LDI activity $[7,10]$. Alignment of this region revealed 35 SNPs in the 150 accessions. Thirty-one SNPs (green-labeled in Figure 5) were significantly associated with LDI activity, explaining $13.4 \%$ of the phenotypic variation and $-\log _{10}(\mathrm{p})$ value of each SNP reaching a highly significant level (Figure 5).

According to polymorphism of 35 SNPs, the 150 barley accessions can be divided into 6 haplotypes: H1-H6. $\mathrm{H} 1-\mathrm{H} 4$ showed high similarity of $H \nu L D I$ sequence, while $\mathrm{H} 5$ and $\mathrm{H} 6$ had the similar sequences (Figure 5). Because the 31 significant SNPs in $H v L D I$ were complete

\begin{tabular}{|c|c|c|c|c|c|c|c|c|c|c|c|c|c|}
\hline & SNP & -434 & -432 & -428 & -416 & -410 & -391 & -389 & -383 & -374 & -369 & -368 & -357 \\
\hline \multirow{6}{*}{ 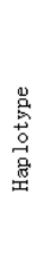 } & H1 & A & $\mathrm{T}$ & $\mathrm{T}$ & $\mathrm{T}$ & G & A & G & $\mathrm{T}$ & A & A & C & A \\
\hline & $\mathrm{H} 2$ & A & $\mathrm{T}$ & $\mathrm{T}$ & $\mathrm{T}$ & G & A & G & $\mathrm{T}$ & A & A & C & $A$ \\
\hline & H3 & A & $\mathrm{T}$ & $\mathrm{T}$ & $\mathrm{T}$ & G & A & G & $\mathrm{T}$ & A & A & $C$ & A \\
\hline & H4 & A & $\mathrm{T}$ & $\mathrm{T}$ & $\mathrm{T}$ & G & G & G & $\mathrm{T}$ & A & A & C & A \\
\hline & H5 & G & $C$ & G & $\mathrm{C}$ & $C$ & A & A & $C$ & - & $\mathrm{T}$ & $\mathrm{T}$ & G \\
\hline & $\mathrm{H} 6$ & G & $C$ & G & $C$ & C & A & A & $C$ & - & $\mathrm{T}$ & $\mathrm{T}$ & G \\
\hline \multicolumn{2}{|c|}{$-\operatorname{LOG}_{10}(\mathrm{p})$} & 5.09 & 5. 09 & 5.09 & 5.09 & 5.09 & & 5.09 & 5.09 & 5.09 & 5. 09 & 5.09 & 5. 09 \\
\hline \multicolumn{2}{|c|}{$\operatorname{mar} \operatorname{ker}^{2}(\%)$} & 13. 4 & 13.4 & 13.4 & 13.4 & 13.4 & & 13. 4 & 13. 4 & 13. 4 & 13.4 & 13.4 & 13.4 \\
\hline & SNP & -353 & -351 & -350 & -343 & -300 & -281 & -272 & -259 & -258 & -257 & -253 & -224 \\
\hline \multirow{6}{*}{ 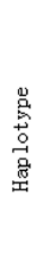 } & H1 & A & - & - & A & A & - & A & A & C & A & $C$ & $\mathrm{~T}$ \\
\hline & $\mathrm{H} 2$ & A & - & - & A & A & - & A & A & $c$ & A & C & C \\
\hline & H3 & A & - & - & A & A & - & A & A & $c$ & A & $c$ & $\mathrm{~T}$ \\
\hline & $\mathrm{H} 4$ & A & - & - & A & A & - & A & A & C & A & C & $\mathrm{T}$ \\
\hline & H5 & $\mathrm{T}$ & $\mathrm{T}$ & $\mathrm{T}$ & $\mathrm{T}$ & G & A & A & - & $\mathrm{T}$ & G & $\mathrm{T}$ & $\mathrm{T}$ \\
\hline & H6 & $\mathrm{T}$ & $\mathrm{T}$ & $\mathrm{T}$ & $\mathrm{T}$ & G & A & G & - & $\mathrm{T}$ & G & $\mathrm{T}$ & $\mathrm{T}$ \\
\hline \multicolumn{2}{|c|}{$-L O G_{10}(p)$} & 5.09 & 5. 09 & 5. 09 & 5. 09 & 5.09 & 5.09 & & 5.09 & 5.09 & 5. 09 & 5.09 & \\
\hline \multicolumn{2}{|c|}{$\operatorname{mar} \operatorname{kerR}^{2}(\%)$} & 13. 4 & 13.4 & 13.4 & 13.4 & 13.4 & 13. 4 & & 13.4 & 13.4 & 13.4 & 13.4 & \\
\hline & SNP & -211 & -142 & -109 & -99 & -59 & 13 & 24 & 72 & 122 & 142 & 352 & \\
\hline \multirow{6}{*}{ 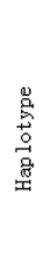 } & H1 & $C$ & A & A & G & G & G & $c$ & G & $c$ & A & A & \\
\hline & $\mathrm{H} 2$ & $C$ & A & A & G & G & G & $c$ & G & $c$ & A & A & \\
\hline & H3 & $C$ & A & A & G & G & G & $C$ & G & $c$ & G & A & \\
\hline & H4 & $C$ & A & A & G & G & $\mathrm{G}$ & $c$ & $G$ & $c$ & A & A & \\
\hline & H5 & G & G & $\mathrm{T}$ & C & A & A & G & A & $\mathrm{T}$ & A & G & \\
\hline & H6 & G & G & $\mathrm{T}$ & $\mathrm{C}$ & A & A & G & A & $\mathrm{T}$ & A & G & \\
\hline \multicolumn{2}{|c|}{$-L_{0} G_{10}(p)$} & 5.09 & 5. 09 & 5. 09 & 5. 09 & 5.09 & 5.09 & 5.09 & 5.09 & 5.09 & & 5.09 & \\
\hline \multicolumn{2}{|c|}{$\operatorname{mar} \operatorname{kerR}^{2}(\%)$} & 13. 4 & 13.4 & 13.4 & 13.4 & 13.4 & 13. 4 & 13.4 & 13.4 & 13. 4 & & 13.4 & \\
\hline
\end{tabular}

Figure 5 Haplotype analysis of the HvLDI using 35 SNPs. The first site of coding region was presented as 0 . The green areas are the SNPS significantly correlated with LDI activity, for which the value of $-\log _{10}(P)>2$. Marker $R^{2}$ is the fraction of the total variation explained by the marker. 
disequilibrium $\left(r^{2}=1\right)$ with each other, they could be regarded as one variant (Additional file 5: Figure S2). Hence, all accessions may be classified into two haplotypes, i.e. HA and HB. Accordingly, the distribution of haplotypes within different subpopulations was investigated. Q1, Q2 and Q5 were mainly constructed by haplotype 1, and Q3 by haplotype 5, whereas Q4 subpopulation showed specificity to other subpopulations for its balanced composition of HA and HB (HA: HB = 18:29). Interestingly, HA showed significantly lower LDI activity than HB in Q4 subpopulation (Figure 6b,c), while there was no difference between them in other subpopulations.

\section{Discussion}

In this study, we investigated the genetic variation of LDI activity and performed GWAS analysis of $H \nu L D I$, in order to identify the loci controlling LDI activity in Tibetan wild barley. A wide variation in LDI activity was found in the 162 Tibetan wild barley accessions, and some of which displayed a minus value. It should be noted that some dextrins released by the de-branching enzymes during germination could also be detected by the Limit-Dextrizyme method, and these dextrins may account for the overestimation of LD activity $[11,32,33]$. Thus, the detected LD activities in extraction solutions of some accessions were higher than those of added LD, resulting in minus values of LDI activity, which was calculated as the reduced LD activity. However, the minus values of LDI in this

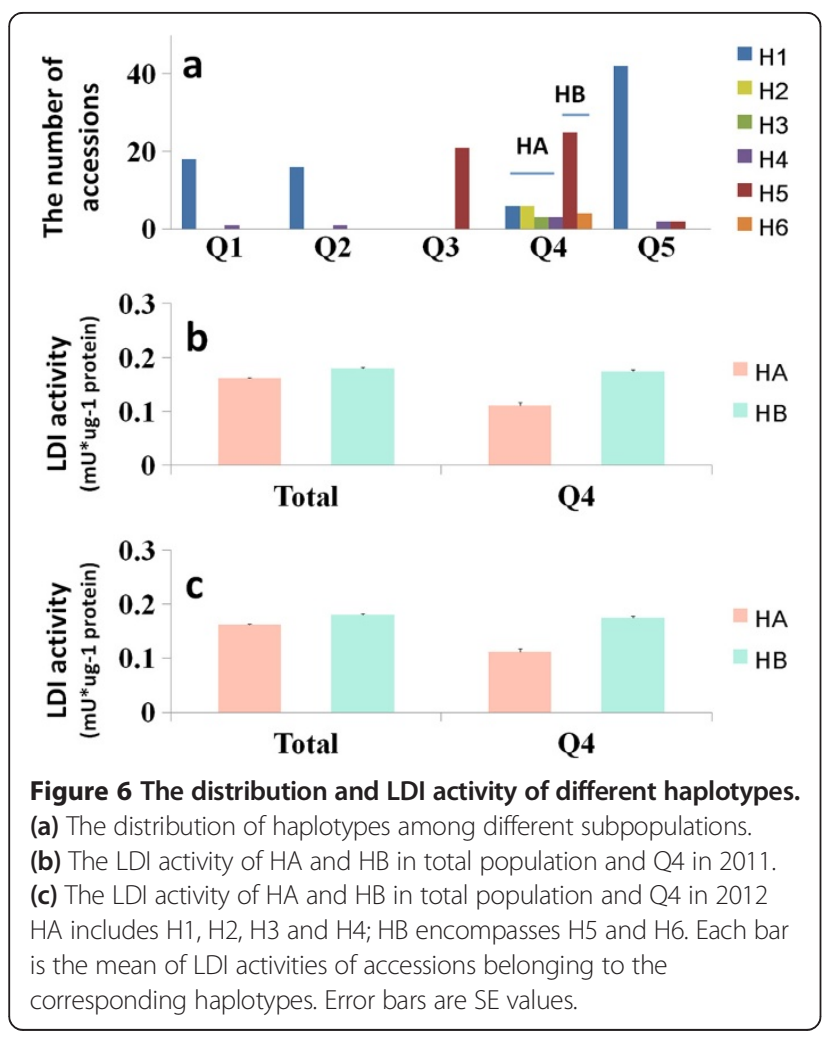

experiment only occurred in very few accessions, and were very small (close to zero). Therefore the accessions with minus values of LDI are quite low in LDI activity. Actually, the impact of these dextrins produced during short-time extraction on the final LDI values could be negligible, as reported by [32].

Two DArT markers, i.e. bpb-8347 and bpb-0068 were found to be associated with LDI activities in Tibetan wild barley. Bpb-8347, a marker with highest GWA peak, is located near the locus of $H v L D I$ gene obtained from IPK database, where the whole barley genome sequences lay [34]. This result confirms that $H v L D I$ is a major gene controlling LDI activity in barley grain. Bpb-0068 might be a potential locus contributing to LDI activity, and it has not been reported up to date. Hence, it may be assumed that some minor effect genes affecting LDI activity may exist in Tibetan wild barley, and need to be confirmed by QTL analysis in segregating population in future work.

A total of 31 SNPs of $H v L D I$ were significantly associated with LDI activity. It is also found that 11 of these SNPs are significantly associated with the malt extract in $56 \mathrm{cul}-$ tivated genotypes in a previous study [19], in which association analysis between $H v L D I$ gene and LDI activity was not conducted. These results indicate that the LDI activity has a close relationship with malt extract, because the two traits are affected by the same 11 SNPs. Indeed, it was previously reported that the $H v L D I$ antisense lines showed unpredicted pleiotropic effects on numerous enzyme activities, including $\alpha$ - and $\beta$-amylases, starch synthases, as well as starch granule types, all of which affect malt extract [35]. In addition, the LD activityassociated SNP in the previous study [19] was not detected in the Tibetan wild population, suggesting that LD activity in malt may be independent on polymorphism of $H v L D I$ gene in Tibetan population.

Interestingly, $\mathrm{HA}$ and $\mathrm{HB}$ showed a significant difference of the LDI activity only in Q4 subpopulation (Figure 6b,c). Q4 contains all kinds of haplotypes, while every other subpopulation mainly consists of one haplotype (Figure 6a). In other word, Q4 has a wider genetic diversity than every other subpopulation. It seems that these associated SNPs are false positive due to highly structured LD (Additional file 5: Figure S2) in this chromosomal region, and similar phenomenon were also observed in association analysis of frost tolerance [36,37]. It may be hypothesized that the variation of LDI activity in Q4 may be caused by other variations, which share linkage disequilibrium with the detected SNPs, in or around this region [34,38]. These variations should only belong to the accessions of HA in Q4 subpopulation, and may exist in the upstream or promoter region of $H v L D I$, or the regulated factors, which co-segregated with the detected SNPs. However, the assumption needs to be confirmed in the further work. 
Four SNPs $(13,24,72$, and 352) within a coding region generate the alteration of the amino acids sequence. But these two kinds of haplotypes showed no significant difference in LDI activity among all accessions. It can be concluded that the alteration of LDI activity may be not due to the change of amino acid composition.

\section{Conclusions}

This study confirmed the locus of LDI gene and detected a DArT marker, bpb-0068, associated with LDI activity. The results provide useful information for identifying minor effect genes affecting LDI activity, and also prove that Tibetan wild barley is an elite germplasm, which may act as an abundant gene pool for barley breeding. Furthermore, the detected SNPs in this study should be helpful for better understanding the genetic control of LDI activity in barley grain.

\section{Additional files}

Additional file 1: Table S1. Minor allele frequency (MAF) and polymorphic information content (PIC) of 835 DArT markers used in this study.

Additional file 2: Figure S1. Phylogenetic tree (neighbor-joining) of 162 barley accessions based on 835 DArT markers.

Additional file 3: Table S2. The value of population structure of 162 accessions. Each accession belongs to the population with the highest value calculated by STRUCTURE software.

Additional file 4: Table S3. GWAS results of bpb-8347 and bpb-0068 under $\mathrm{Q}, \mathrm{K}, \mathrm{Q}+\mathrm{K}$ methods.

Additional file 5: Figure S2. Decay of linkage disequilibrium (LD) of HVLDI gene in Tibetan wild barley. Each point in the LD matrix represents a comparison between a pair of polymorphic sites. Different colors represent different levels of LD.

\section{Competing interests}

The authors declare that they have no competing interests.

\section{Authors' contributions}

$\mathrm{YH}, \mathrm{GZ}$ and $\mathrm{CL}$ designed the experiment, $\mathrm{YH}$ and SC determined the LDI activity, GWAS analysis and drafted the manuscript. LY and YH participated in the sequence alignment. DW and FD performed the data analysis. All authors read and approved the final manuscript.

\section{Acknowledgments}

This research was supported by National Natural Science Foundation of China (Nos. 31330055, 31271656, 31129005), Zhejiang Provincial Natural Science Foundation of China (No. Z3110054) and China Agriculture Research System. We thank Mr Xianyin Zhang and Ms. Mei Li, the technicians of 985-Institute of Agrobiology for providing convenience in using the experimental equipments.

\section{Author details}

${ }^{1}$ Agronomy Department, Key Laboratory of Crop Germplasm Resource of Zhejiang Province, Zhejiang University, Hangzhou 310058, China.

${ }^{2}$ Department of Agriculture and Food, Western Australia, WA 6983, Australia.

Received: 27 January 2014 Accepted: 28 April 2014

Published: 1 May 2014

\section{References}

1. Fincher GB: Molecular and cellular biology associated with endosperm mobilisation in germinating cereal grains. Annu Rev Plant Physiol Plant Mol Biol 1989, 40:305-346.
2. Vasanthan T, Hoover R: Barley starch: production, properties, modification and uses. In Starch: Chemistry and Technology. 3rd edition. Edited by BeMiller J, Whistler R. New York: Academic press; 2009:601-628.

3. Manners DJ: Starch degradation during malting mashing. Brewers Digest 1974, 49:56-62.

4. Manners DJ, Marshall JJ, Yellowlees D: The specificity of cereal limit dextrinase. Biochem J 1970, 116:539-541.

5. Panchal CJ, Stewart GG: Utilisation of wort carbohydrates. Brewers Digest 1979, 54:36-43.

6. Sissons MJ, Lance RCM, Wallace W: Bound and free forms of barley limit dextrinase. Cereal Chem 1994, 71:520-521.

7. Macri LJ, MacGregor AW, Shroeder SW, Bazin SL: Detection of a limit dextrinase inhibitor in barley. J Cereal Sci 1993, 18:103-106.

8. MacGregor AW, Donald LJ, MacGregor EA, Duckworth HW: Stoichiometry of the complex formed by barley limit dextrinase with its endogenous inhibitor. Determination by electrospray time-of-flight mass spectrometry. J Cereal Sci 2003, 37:357-362.

9. Sissons M, Taylor M, Proudlove M: Barley malt limit dextrinase: its extraction, heat stability and activity during malting and mashing. J Am Soc Brew Chem 1995, 53:104-110.

10. Karakousis A, Barr AR, Kretschmer JM, Manning S, Logue SJ, Roumeliotis S, Collins HM, Chalmers KJ, Li CD, Lance RCM, Langridge P: Mapping and QTL analysis of the barley population Galleon $\times$ Haruna Nijo. Aust J Agr Res 2003, 54(12):1131-1135.

11. Stahl Y, Alexander RD, Coates S, Bryce JH, Jenkinson HR, Morris PC: The barley limit dextrinase inhibitor: Gene expression, protein location and interaction with 14-3-3 protein. Plant Sci 2007, 172:452-461.

12. Wu DZ, Qiu L, Xu LL, Ye LZ, Chen MX, Sun DF, Chen ZH, Zhang HT, Jin XL, Dai F, Zhang GP: Genetic Variation of HvCBF Genes and Their Association with Salinity Tolerance in Tibetan Annual Wild Barley. PLoS One 2011, 6(7):e22938.

13. Dai F, Nevo E, Wu D, Comadran J, Zhou M, Qiu L, Chen ZH: Avigdor Beiles, Chen GX, Zhang GP: Tibet is one of the centers of domestication of cultivated barley. Proc Natl Acad Sci U S A 2012, 109(42):16969-16973.

14. Nguyen Viet L, Oene D, Marcos M, Benjamin K, Andreas G, Richard GF, Visser C, Gerard Van Der L: Association mapping of salt tolerance in barley (Hordeum vulgare L.). Theor App/ Genet 2013. doi:10.1007/ s00122-013-2139-0.

15. Long NV, Dolstra O, Malosetti M, Kilian B, Graner A, Visser RG, Van Der Linden CG: Association mapping of salt tolerance in barley (Hordeum vulgare L.). Theor Appl Genet 2013. doi:10.1007/s00122-013-2139-0.

16. Neumann K, Kobiljski B, Dencic S, Varshney RK, Borner A: Genome-wide association mapping: a case study in bread wheat (Triticum aestivum L.). Mol Breeding 2011, 27:37-58.

17. Pasam RK, Sharma R, Malosetti M, Van Eeuwijk FA, Haseneyer G, Kilian B, Graner A: Genome-wide association studies for agronomical traits in a world wide spring barley collection. BMC Plant Biol 2012, 12:16.

18. Cai SG, Yu G, Chen XH, Huang YC, Jiang XG, Zhang GP, Jin XL: Grain protein content variation and its association analysis in barley. BMC Plant Biol 2013, 13:35.

19. Jin XL, Cai SG, Ye LZ, Chen ZH, Zhou MX, Zhang GP: Association of HvLDI with limit dextrinase activity and malt quality in barley. Biotechnol Lett 2013, 35:639-645.

20. Kristensen M, Planchot $\mathrm{V}$, Abe J, Svensson B: Large-scale purification and characterization of barley limit dextrinase, a member of the alpha amylase structural family. Cereal Chem 1998, 75:473-479.

21. MacGregor AW, Macri LJ, Schroeder SW, Bazin SL: Purification and characterization of limit dextrinase inhibitors from barley. J Cereal Sci 1994, 20:33-41.

22. Pritchard JK, Stephens M, Donnelly P: Inference of population structure using multilocus genotype data. Genetics 2000, 155:945-959.

23. Wenzl P, Li H, Carling J, Zhou M, Raman H, Paul E, Hearnden P, Maier C, Xia L, Caig V, Jaroslava O, Mehmet C, David P, Junping W, Rosy R, Smith KP, Muehlbauer GJ, Chalmers KJ, Andris K, Eric H, Andrzej K: A high-density consensus map of barley linking DArT markers to SSR, RFLP and STS loci and agricultural traits. BMC Genomics 2006, 7(1):206.

24. Wenzl P, Carling J, Kudrna D, Jaccoud D, Huttner E, Kleinhofs A, Kilian A: Diversity Arrays Technology (DArT) for whole-genome profiling of barley. Proc Natl Acad Sci U S A 2004, 15(26):9915-9920. doi:10.1073/ pnas.0401076101. 
25. Alsop BP, Farre A, Wenzl P, Wang JM, Zhou MX, Romagosa I, Kilian A, Steffenson BJ: Development of wild barley-derived DArT markers and their integration into a barley consensus map. Mol Breeding 2011, 27:77-92. doi:10.1007/s11032-010-9415-3.

26. Evanno G, Regnaut $\mathrm{S}$, Goudet J: Detecting the number of clusters of individuals using the software STRUCTURE: a simulation study. Mol Ecol 2005, 14:2611-2620.

27. Hardy OJ, Vekemans X: Spagedi: a versatile computer program to analyze spatial genetic structure at the individual or population levels. Mol Ecol Notes 2002, 2:618-620.

28. Bradbury PJ, Zhang ZW, Kroon DE, Casstevens TM, Ramdoss Y, Buckler ES: TASSEL: software for association mapping of complex traits in diverse samples. Bioinformatics 2007, 23(19):2633-2635.

29. Huang JC, Ge XJ, Sun M: Modified CTAB protocol using a silica matrix for isolation of plant genomic DNA. Biotechniques 2000, 28:432-434.

30. Tamura K, Peterson D, Peterson N, Stecher G, Nei M, Kumar S: MEGA5: Molecular evolutionary genetics analysis using maximum likelihood, evolutionary distance, and maximum parsimony methods. Mol Biol Evol 2011, 28:2731-2739

31. Librado P, Rozas J: DnaSP v5: a software for comprehensive analysis of DNA polymorphism data. Bioinform Appl Note 2009, 25:1451-1452.

32. MacGregor AW, Bazin SL, Schroedor SW: Effect of starch hydrolysis products on the determination of limit dextrinase and limit dextrinase inhibitors in barley and malt. J Cereal Sci 2002, 35:17-28.

33. McDougall GJ, Ross HA, Swanston JS, Davies HV: Limit dextrinase from germinating barley has endotransglycosylase activity, which explains its activation by maltodextrins. Planta 2004, 218:542-551.

34. Mayer KF, Waugh R, Brown JW, Schulman A, Langridge P, Platzer M, Fincher GB, Muehlbauer GJ, Sato K, Close TJ, Wise RP, Stein N, International Barley Genome Sequencing Consortium: A physical, genetic and functional sequence assembly of the barley genome. Nature 2012, 491:711-717.

35. Stahl Y, Coates S, Bryce JH, Morris PC, Morris PC: Antisense downregulation of the barley limit dextrinase inhibitor modulates starch granule size distribution, starch composition and amylopectin structure. Plant J 2004, 39:599-611.

36. Fricano A, Rizza F, Faccioli P, Pagani D, Pavan P, Stella A, Rossini L, Piffanelli $P$, Cattivelli L: Genetic variants of HvCbf14 are statistically associated with frost tolerance in a European germplasm collection of Hordeum vulgare. Theor Appl Genet 2009, 119:1335-1348.

37. Visioni A, Tondelli A, Francia E, Pswarayi A, Malosetti M, Russell J, Thomas W, Waugh R, Pecchioni N, Romagosa I, Jordi C: Genome-wide association mapping of frost tolerance in barley (Hordeum vulgare L.). BMC Genomics 2013, 14:424.

38. Myles S, Davison D, Barrett J, Stoneking M, Timpson N: World wide population differentiation at disease associated SNPs. BMC Genomics 2008, 1:22.

doi:10.1186/1471-2229-14-117

Cite this article as: Huang et al:: Genetic architecture of limit dextrinase inhibitor (LDI) activity in Tibetan wild barley. BMC Plant Biology 2014 14:117.

\section{Submit your next manuscript to BioMed Central and take full advantage of:}

- Convenient online submission

- Thorough peer review

- No space constraints or color figure charges

- Immediate publication on acceptance

- Inclusion in PubMed, CAS, Scopus and Google Scholar

- Research which is freely available for redistribution 